JJTM, Vol. 7 No.3 Tahun:2019

\title{
RANCANG BANGUN AIR COOLER DENGAN MENGGUNAKAN MODUL TERMOELEKTRIK PELTIER TYPE TEC-12706
}

\author{
Kadek Budi Rohito ${ }^{1}$, K. Rihendra Dantes ${ }^{1}$, I. N. Pasek Nugraha ${ }^{2}$ \\ Program Studi Pendidikan Teknik Mesin, Fakultas Teknik \& Kejuruan \\ Universitas Pendidikan Ganesha \\ Singaraja, Indonesia \\ e-mail: kadek.budi.rohito@undiksha.ac.id ${ }^{1}$, rihendra-dantes@undiksha.ac.id ${ }^{1}$, \\ paseknugraha@undiksha.ac.id²
}

\begin{abstract}
ABSTRAK
Tujuan penelitian ini adalah untuk mengetahui bagaimana perancangan air cooler yang sesuai dengan kebutuhan masyarakat yang menginginkan suatu alat penyejuk ruangan yang berbentuk mini dan harga jual yang tidak terlalu mahal. Bahan yang digunakan pada rancangan air cooler menggunakan bahan mika setebal $3 \mathrm{~mm}$ dengan menggunakan ukuran $40 \times 40 \times 50 \mathrm{~cm}$. Hasil maksimal yang didapat pada air cooler dalam pengambilan data pertama didapatkan suhu maksimal 15.3 derajat pada waktu 5 menit. Dalam pengambilan data kedua didapatkan suhu maksimal yang dicapai adalah 14.7 derajat pada waktu 5 menit. Dalam pengambilan data ketiga didapat capaian suhu maksimal 14.6 derajat pada waktu 5 menit. Dalam pengambilan data keempat didapat capaian suhu maksimal 15.3 derajat pada waktu 5 menit. Dalam pengambilan data kelima didapat suhu maksimal 15.7 derajat pada menit 5 menit. Rata-rata capaian suhu pertama yang didapatkan dalam pengambilan data yang sudah dilakukan sebanyak 5 kali dalam waktu 5 menit adalah 15.12. Rata-rata ke dua suhu yang didapat dalam pengambilan data selama 10 menit sebanyak 5 kali adalah 15.46. Rata-rata ke tiga suhu yang didapat dalam pengambilan data selama 15 menit sebanyak 5 kali adalah 15.68 . Rata-rata ke empat suhu yang didapat dalam pengambilan data selama 20 menit sebanyak 5 kali adalah 15.48 . Rata-rata ke lima suhu yang didapat dalam pengambilan data selama 25 menit sebanyak 5 kali adalah 15.68. Rata-rata ke enam suhu yang didapat dalam pengambilan data selama 30 menit sebanyak 5 kali adalah 15.64. Dari data diatas didapatkan hasil yang berbeda yang sudah dilakukan pengujian sebanyak 5 kali dengan waktu perlima menit, yang dikarenakan adanya pengaruh suhu yang berada pada ruangan, yang dimana terjadi perbedaan temperature ruangan yang di akibatkan oleh panas matahari yang menyebabkan suhu ruangan menjadi naik.
\end{abstract}

Kata kunci : Air cooler, peltier, ,teknik pendingin.

\section{ABSTRACT}

The purpose of this study is to find out how to design an air cooler that suits the needs of people who want a mini air conditioner and the sale price is not too expensive. The material used in the design of the air cooler uses a $3 \mathrm{~mm}$ thick mica material using a size of $40 \times 40 \times 50$ $\mathrm{cm}$. The maximum results obtained in the air cooler in the first data collection obtained a maximum temperature of 15.3 degrees in 5 minutes. In taking the second data, the maximum temperature reached was 14.7 degrees in 5 minutes. In the third data retrieval obtained maximum temperature achievements of 14.6 degrees within 5 minutes. In taking the fourth data, the maximum temperature was 15.3 degrees in 5 minutes. In taking the fifth data, the maximum temperature is 15.7 degrees in 5 minutes. The first average temperature achievement obtained in data retrieval that has been done 5 times in 5 minutes is 15.12. The average of the two temperatures obtained in data collection for 10 minutes 5 times is 15.46. The average of the three temperatures obtained in data retrieval for 15 minutes 5 times is 15.68. The average of the four temperatures obtained in taking data for 20 minutes 5 times is 15.48 . The average of the five temperatures obtained in taking data for 25 minutes 5 times is 15.68 . The average of the six temperatures obtained in data 
retrieval for 30 minutes 5 times is 15.64 . From the above data obtained different results that have been tested 5 times with a fifth of the time, which is due to the influence of temperature in the room, which occurs when there is a difference in the temperature of the room caused by the heat of the sun which causes the room temperature to rise.

Keywords: Air cooler, peltier, cooling technique.

\section{Pendahuluan}

Pembangunan bidang industri di Indonesia pada hakekatnya adalah untuk mengurangi ketergantungan pada bangsa lain sehingga kita mampu memproduksi kebutuhan-kebutuhan yang kita perlukan dan dengan sendirinya terjadi peningkatan perkembangan ekonomi dan peningkatan lapangan kerja.Sampai saat ini telah banyak percobaan dari riset yang mendalam terus menerus dilakukan untuk mengembangkan teknologi khsusnya dibidang teknik mesin yang pada akhirnya memunculkan berbagai macam teknologi baru.

Teknologi di bidang pendingin pada saat ini semakin banyak dimanfaatkan untuk meningkatnya taraf hidup. Penggunaan yang umum adalah untuk mengawetkan makanan dan juga sebagai penyejuk ruangan. Pendingin ruangan atau air cooler yang beredar dipasaran memiliki harga kisaran dari 1.3 juta sampai 1.7 juta rupiah dengan konsumsi daya listrik yang diperlukan adalah 220-240v $100 \mathrm{~W}$ dengan dimensi $360 \times 300$ x $760 \mathrm{~mm}$. Air cooler yang beredar dipasaran memiliki ukuran dimensi yang cukup besar sehingga alat penyejuk ruangan ini tidak bisa portable dan daya listrik yang diperlukan untuk menghidupkan air cooler yang beredar dipasaran juga terlalu besar.

Pada pembahasan kali ini khusus membahas tentang penyejuk ruangan yang hemat energi dan juga hanya memerlukan sedikit tempat untuk penempatannya.Tugas utama air cooler bukan untuk mendinginkan ruangan melainkan digunakan hanya untuk menyejukan ruangan.

Air cooler menggunakan bahan pendingin air yang dimana uap dingin yang dihasilkan akan disemburkan menggunakan fan sehingga menghasilkan udara yang sejuk, Sedangkan penggunaan kipas angin jika didalam ruangan bersuhu panas maka suhu panaslah yang akan di semburkan oleh fan.

Maka dari itu air cooler sebagai penyejuk ruangan sangat efektif dalam menyejukan ruangan,menghemat daya listrik, sangat ramah lingkungan,dan juga tidak menghabiskan banyak tempat.

Disini lah penulis berinisiatif untuk menciptakan atau melalukan suatu rancang bangun sistem penyejuk ruangan yang efisien dan harganya juga tidak terlalu mahal,penggunaan listrik pun tidak terlalu banyak sehingga masyarakat yang memiliki ekonomi sedang masih bisa membeli alat pendingin ruangan yang harganya masih bisa terjangkau oleh masyarakat yang ingin menggunakan penyejuk ruangan.

Air cooler dengan menggunakan thermoelektrik peltier ini hanya memerlukan sedikit lebihnya waktu 20 menit untuk mendinginkan heatsink. Selain itu juga rancang bangun air cooler ini juga dapat digunakan untuk media praktek dalam Program Studi Pendidikan Teknik Mesin Universitas Pendidikan Ganesha

\section{METODE PENELITIAN}

Desain penelitian yang digunakan dalam tahap penelitian ini adalah penelitian dan pengembangan. Metode Penelitian dan Pengembangan

(Researchand Development) adalah metode penelitian yang digunakan untuk menghasilkan produk tertentu, dan menguji keefektifan produk tersebut.

Menurut Sujadi (2003:164) Penelitian dan Pengembangan atau Research and Development (R\&D) adalah suatu proses atau langkah-langkah untuk mengembangkan suatu produk baru, atau menyempurnakan produk yang telah ada, yang dapat dipertanggungjawabkan. Sugiyono (2015: 407) adapun langkah 
pelaksanaan strategi penelitian dan pengembangan yang dilakukan untuk menghasilkan produk tertentu untuk menguji keefektifan produk yang dimaksud. Sesuai dengan batasan masalah yang ditetapkan, penelitian Rancang bangun Air cooler dengan menggunakan modul thermoeletrik peltier type TEC-12706 dilakukan sampai tahap revisi produk.

Quality Function Deployment (QFD) merupakan suatu metode yang dipakai dalam tahap awal perancangan dan pengembangan produk dimana membuat rancangan kualitas dari suatu produk berdasarkan atas permintaan kualitas dari pemesanan (Customer) atau pasar (Market). QFD merupakan metode yang digunakan untuk mengantisipasi dan menentukan prioritas kebutuhan dan keiinginan konsumen, serta menggabungkan kebutuhan dan keiinginan konsumen tersebut dalam produk barang maupun jasa yang dihasilkan perusahaan.

Pengujian dilakukan berdasarkan penyebaran angket free energy generator pada Permintaan Kualitas Customer (PKC), uji ahli materi, selanjutnya dilakukan uji kelompok kecil dan uji kelompok besar (uji lapangan).

Untuk mengetahui tingkat kelayakan dari segi desain dan dimensi melalui angket skala ordinal dengan tingkatan 5 (kategori Sangat Setuju/SS), 4 (kategori Setuju/S), 3 (kategori ragu-ragu), 2 (kategori Tidak Setuju/TS), 1 (kategori Sangat Tidak Setuju/STS) untuk pernyataan positif dan 1 (kategori Sangat Setuju/SS), 2 (kategori Setuju/S), 3 (kategori ragu-ragu), (kategori Tidak Setuju/TS), 5 (kategori Sangat Tidak Setuju/STS) untuk pernyataan bersifat negatif.

\section{Hasil Penelitian}

Penelitian ini merancang sebuah penyejuk ruangan yang bernama air cooler yang menggunakan thermoelektrik peltier sebagai alat pendinginan. Thermoelektrik yang digunakan pada air cooler adalah dengan tipe TEC-12706. Ukuran yang digunakan dalam pembuatan bodi air cooler adalah $40 \times 40 \times 50 \mathrm{~cm}$, ukuran ini digunakan karena untuk memenuhi kebutuhan konsumen yang menginginkan alat penyejuk ruangan yang memiliki ukuran yang kecil atau mini.

Berdasarkan hasil penelitian yang sudah dilakukan dijelaskan bahwa capaian suhu maksimal air cooler Mini dalam pengambilan data sebanyak 5 kali yang dilakukan selama 5 sampai 30 menit didapatkan hasil sebagai berikut:

Hasil maksimal yang didapat pada air cooler dalam pengambilan data pertama didapatkan suhu maksimal 15.3 derajat pada waktu 5 menit. Dalam pengambilan data kedua didapatkan suhu maksimal yang dicapai adalah 14.7 derajat pada waktu 5 menit. Dalam pengambilan data ketiga didapat capaian suhu maksimal 14.6 derajat pada waktu 5 menit. Dalam pengambilan data keempat didapat capaian suhu maksimal 15.3 derajat pada waktu 5 menit. Dalam pengambilan data kelima didapat suhu maksimal 15.7 derajat pada menit 5 menit. Rata-rata capaian suhu pertama yang didapatkan dalam pengambilan data yang sudah dilakukan sebanyak 5 kali dalam waktu 5 menit adalah 15.12 .

Rata-rata ke dua suhu yang didapat dalam pengambilan data selama 10 menit sebanyak 5 kali adalah 15.46. Rata-rata ke tiga suhu yang didapat dalam pengambilan data selama 15 menit sebanyak 5 kali adalah 15.68 . Rata-rata ke empat suhu yang didapat dalam pengambilan data selama 20 menit sebanyak 5 kali adalah 15.48. Ratarata ke lima suhu yang didapat dalam pengambilan data selama 25 menit sebanyak 5 kali adalah 15.68. Rata-rata ke enam suhu yang didapat dalam pengambilan data selama 30 menit sebanyak 5 kali adalah 15.64. Dari data 
JJTM, Vol. 7 No.3 Tahun:2019

diatas didapatkan hasil yang berbeda yang sudah dilakukan pengujian sebanyak 5 kali waktu perlima menit, yang dikarenakan adanya pengaruh suhu yang berada pada ruangan, yang dimana terjadi

perbedaan temperature ruangan yang di akibatkan oleh panas matahari yang menyebabkan suhu ruangan menjadi naik.

Tabel dibawah menunjukan hasil dari validitas uji ahli, kelompok kecil, dan kelompok besar

\begin{tabular}{|c|c|c|}
\hline & Item petanyagn & Sker rata-rata \\
\hline \multicolumn{3}{|c|}{ A. Penilaian Detsain } \\
\hline 1. & 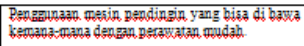 & 4 \\
\hline 2. & A.emfiliki whuran $\min 140 \times 40 \times 50 \mathrm{~cm}$ & 4 \\
\hline 3. & Kesesusaian ukuran produk dengan dessin. & 4 \\
\hline \multicolumn{3}{|c|}{ B. Penilaian alat } \\
\hline 4. & 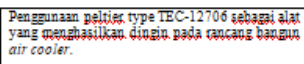 & 4 \\
\hline 5. & 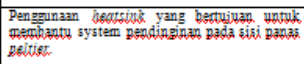 & 4 \\
\hline 6. & 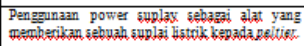 & 4 \\
\hline 7. & 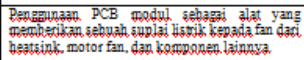 & 4 \\
\hline 8. & 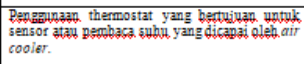 & 4 \\
\hline 9. & 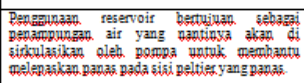 & 4 \\
\hline 10 & 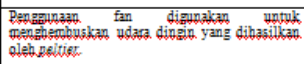 & 4 \\
\hline
\end{tabular}

\begin{tabular}{|c|c|c|}
\hline No & Item pettanyan & Stegr rata-rata \\
\hline \multicolumn{3}{|c|}{ A. Penilaian Dessain } \\
\hline 1. & 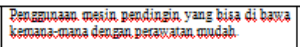 & 3.6 \\
\hline 2. & Nempiliki ykuxan mini $40 \times 40 \times 50 \mathrm{~cm}$ & 3.6 \\
\hline 3. & Kesesusian ykuxam produk dengan desain. & 3.8 \\
\hline \multicolumn{3}{|c|}{ B. Penilaian alat } \\
\hline 4. & 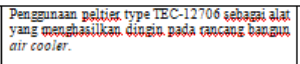 & 3.6 \\
\hline 5. & 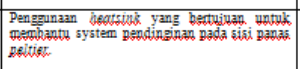 & 4 \\
\hline 6. & 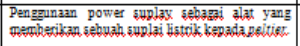 & 3.6 \\
\hline 7. & 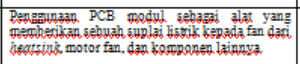 & 3.6 \\
\hline 8. & 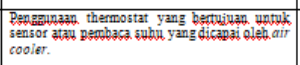 & 3.6 \\
\hline 9 & 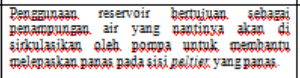 & 3.8 \\
\hline 10. & 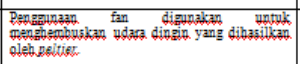 & 4 \\
\hline
\end{tabular}

Setelah

mengetahui kebutuhan masyarakat, kemudian

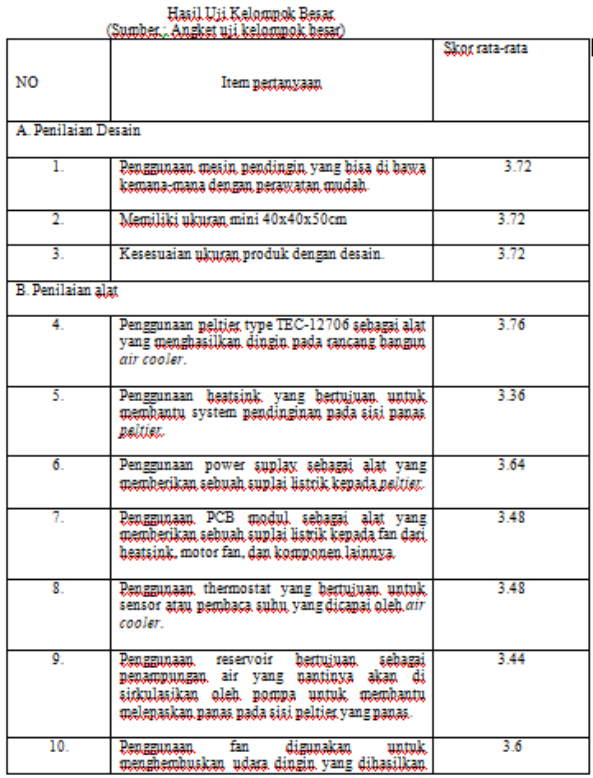

dilakukan perbaikan atau pengembangan dari perancangan yang telah dibuat. Selanjutnya melakukan pembuatan alat, dan terakhir uji coba. pembuatan alat, dan terakhir uji coba.

Rancangan air cooler

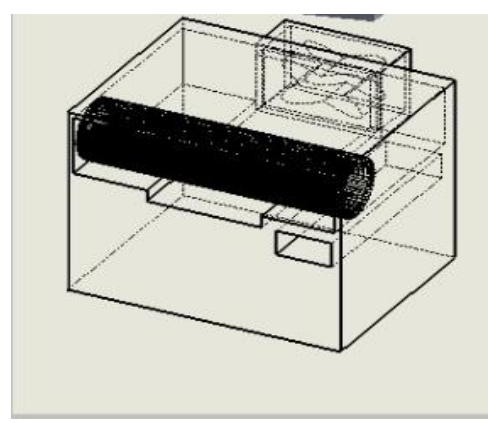

Rancangan air cooler tampak depan

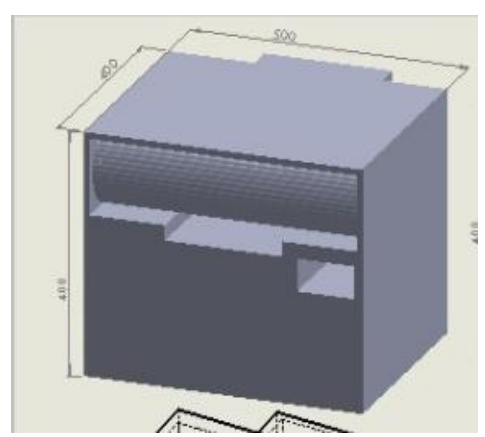


Rancangan air cooler tampak belakang

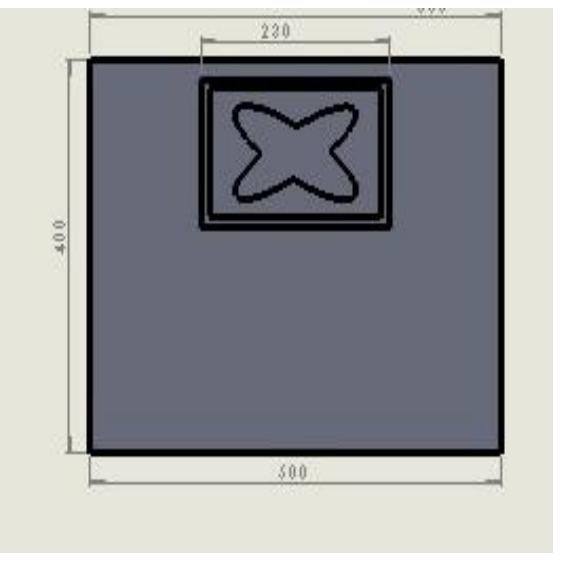

Berikut table hasil pengujian air cooler Berikut adalah spesifikasi Air cooler Mini :

\begin{tabular}{|l|l|}
\hline Nama Alat & Air cooler mini \\
\hline Jenis & Mesin Pendingin \\
\hline Fungsi Alat & $\begin{array}{l}\text { Penyejuk } \\
\text { Ruangan }\end{array}$ \\
\hline $\begin{array}{l}\text { Bentuk Alat } \\
\text { Keseluruhan } \\
\text { Dimensi : } \\
\text { - Panjang }\end{array}$ & $40 \mathrm{~cm}$ \\
- Lebar & $40 \mathrm{~cm}$ \\
\hline
\end{tabular}

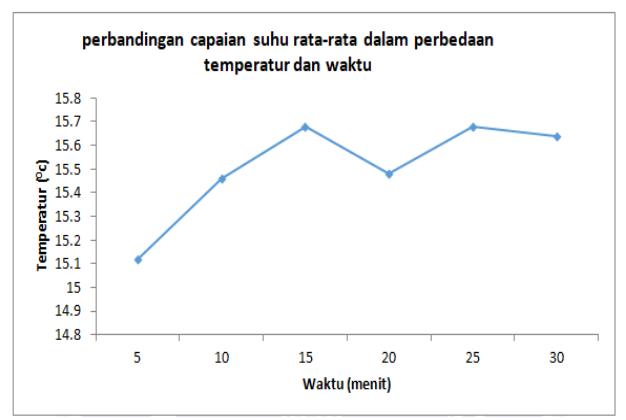

grafik pencapain suhu air cooler

Ada beberapa komponen yang dimiliki air cooler Mini ini, diantaranya :

a. Body

Body dari air cooler ini dirancang dengan ukuran panjang $40 \mathrm{~cm}$, lebar $40 \mathrm{~cm}$, dan tinggi $50 \mathrm{~cm}$. ukuran ini jauh lebih kecil sehingga tidak

\begin{tabular}{|c|c|c|c|c|c|c|}
\hline \multicolumn{7}{|c|}{ Dabel 4.5 } \\
\hline Waktu & Suhu 1 & Suhu 2 & Suhu 3 & Suhu 4 & Suhu 5 & Rata-rata \\
\hline 5 menit & 15.3 & 14.7 & 14.6 & 15.3 & 15.7 & 15.12 \\
\hline 10 menit & 15.5 & 15.2 & 15.3 & 15.5 & 15.8 & 15.46 \\
\hline 15 menit & 15.9 & 15.1 & 15.7 & 15.9 & 15.8 & 15.68 \\
\hline 20 menit & 15.5 & 15.1 & 15.6 & 15.5 & 15.7 & 15.48 \\
\hline 25 menit & 15.8 & 15.5 & 15.5 & 15.8 & 15.8 & 15.68 \\
\hline 30 menit & 15.8 & 15.1 & 15.7 & 15.8 & 15.8 & 15.64 \\
& & & & & & \\
\hline
\end{tabular}

\begin{tabular}{|c|c|}
\hline - $\quad$ Tinggi & \\
\hline $\begin{array}{ll}\text { Bahan } & \text { dan } \\
\text { Kontruksi } & \\
\text { - Body } & \end{array}$ & Mika 3cm \\
\hline $\begin{array}{cl}\text { Peltier } & \\
\text { - } & \text { Arus Optimal } \\
\text { - } & \text { Tegangan } \\
& \text { Optimal } \\
\text { - } & \text { Daya } \\
& \text { Optimal }\end{array}$ & $\begin{array}{l}6 \mathrm{~A} \\
12 \mathrm{~V} \\
72 \text { Watt }\end{array}$ \\
\hline
\end{tabular}

memerlukan banyak tempat dan juga mudah dipindahkan. Bahan yang digunakan adalah mika $3 \mathrm{~mm}$ sebagai body.

b. Peltier TEC 12706

Adalah komponen terpenting pada air cooler karna Berfungsi sebagai penghasil udara dingin pada air cooler Mini. Type peltier yang digunakan adalah TEC-12706 sebanyak 1 buah.

c. Heatsink

Heatsink yang digunakan berupa sirip-sirip dan ditambah kipas CPU dan cooling heatsink sebagai pembuang panasnya.

d. Termostaat berfungsi sebagai indicator pembaca suhu pada air cooler Mini.

e. Power supply 12 V DC 
Power supply berfungsi untuk merubah tegangan AC menjadi tegangan DC karena komponen dari rancangan air cooler Mini seluruhnya memerlukan supply arus DC $12 \mathrm{~V}$. spesifikasi power supply yang digunakan :

- AC input : $110 \mathrm{~V} / 240 \mathrm{~V}$

- DC output : 12V-24V

f. Kipas CPU

Berfungsi sebagai penghembus pada sisi panas dan juga sisi dingin.

\section{Kesimpulan}

Kesimpulan dari rancang bangun air cooler menggunakan thermoelektrik peltier type TEC-12706 adalah Air cooler menggunakan bahan mika setebal $3 \mathrm{~mm}$ sebagai cover atau bodi dan memiliki ukuran $40 \times 40 \times 50$. Komponen yang digunakan pada air cooler yaitu peltier type TEC-12706, PCB modul, power suplay, fan, reservoir, dan motor fan.

Hasil pengujian yang sudah dilakukan dijelaskan bahwa capaian suhu maksimal air cooler Minidalam pengambilan data sebanyak 5 kali yang dilakukan selama 5 sampai 30 menit didapatkan hasil sebagai berikut:

Hasil maksimal yang didapat pada air cooler dalam pengambilan data pertama didapatkan suhu maksimal 15.3 derajat pada waktu 5 menit. Dalam pengambilan data kedua didapatkan suhu maksimal yang dicapai adalah 14.7 derajat pada waktu 5 menit. Dalam pengambilan data ketiga didapat capaian suhu maksimal 14.6 derajat pada waktu 5 menit. Dalam pengambilan data keempat didapat capaian suhu maksimal 15.3 derajat pada waktu 5 menit. Dalam pengambilan data kelima didapat suhu maksimal 15.7 derajat pada menit 5 menit. Rata-rata capaian suhu pertama yang didapatkan dalam pengambilan data yang sudah dilakukan sebanyak 5 kali dalam waktu 5 menit adalah 15.12. Rata-rata ke dua suhu yang didapat dalam pengambilan data selama 10 menit sebanyak 5 kali adalah 15.46.

Rata-rata ke tiga suhu yang didapat dalam pengambilan data selama 15 menit sebanyak 5 kali adalah 15.68 . Rata-rata ke empat suhu yang didapat dalam pengambilan data selama 20 menit sebanyak 5 kali adalah 15.48 .

Rata-rata ke lima suhu yang didapat dalam pengambilan data selama 25 menit sebanyak 5 kali adalah 15.68. Rata-rata ke enam suhu yang didapat dalam pengambilan data selama 30 menit sebanyak 5 kali adalah 15.64. Dari data diatas didapatkan hasil yang berbeda yang sudah dilakukan pengujian sebanyak 5 kali dengan waktu perlima menit, yang dikarenakan adanya pengaruh suhu yang berada pada ruangan, yang dimana terjadi perbedaan temperature ruangan yang di akibatkan oleh panas matahari yang menyebabkan suhu ruangan menjadi naik.

\section{Saran}

Adapun saran yang penulis dapat sampaikan adalah sebagai berikut:

1. Jika ingin memaksimalkan suhu yang dihasilkan bisa dengan memvariasikan Rpm blower yang membantu system pendinginan dari sisi peltier yang panas.

2. Perlunya modifikasi pada reservoir agar panas air yang disirkulasikan menuju peltier dapat di dinginkan kembali.

3. Perlunya penambahan peltier pada evaporator yang bisa meningkatkan suhu dingin yang dihasilkan pada rancang bangun air cooler

4. Perlunya penambahan fan di bagian atas reservoir yang bertujuan untuk membantu pendinginan air yang sudah di sirkulasikan oleh pompa menuju sisi peltier yang panas.

\section{Daftar Rujukan}

Gandi, Frima. 2016. Perancangan System Pendingin Air Menggunakan Elemen Peltier Berbasis Microkontroler ATmega8535, Jurnal fisika Unand vol. 5, no 1. 
Nugroho, Wahyu. 2016. Rancang Bangun Alat Pendingin Minuman Portable Menggunakan Peltier. Pontianak: Universitas Muhammadiyah

Nasution, Mahdian. 2013. Rancang Bangun Dan Analisis Thermoelektrik Peltier Cooler Untuk System Pendingin. Medan: Universitas Sumatra Utara

Purmanasari, Desi. 2017.Perancangan Kotak Pendingin Dan Penghangat Minuman Menggunakan Modul Thermoelektrik Peltier TEC 1-12706 Berbasis Mikrokontroler Arduino Uno. Bandar Lampung: Universitas Lampung
Priyambada, Sandya. 2012. Pendingin Kabin Mobil Berbasis Thermoelektrik. Depok:

Universitas Indonesia

R.Umboh. 2009. Perancangan alat pendingin portable menggunakan elemen peltier. Manado: universitas sam ratulangi Rahman, Maman. 2013. Menganalisis Pendingin Thermoelektrik Dengan Menggunakan Photovoltaic Sebagai Sumber Energy. Bandung: Universitas Pendidikan Indonesia

Sulistianto, Nanang. 2014. Pemodelan System Pendingin Thermoelektrik Pada Modul Superluminance LED. Malang:Universitas Brawijaya Malang 